\title{
Network Social Responsibility
}

\author{
Antonella Zucchella*
}

\begin{abstract}
The value proposition of the firm to its market is not merely the result of "value extraction" across the world, by exploiting local resources and capabilities, but for a growing number of firms is a blend of value and values proposition, based on socially responsive behaviour.

A values chain shift the emphasis from the practice of corporate social responsibility to the one of network social responsibility.

Coordination of the network value chain is not just a matter of improving business performance, but it turns into a strategic matter of guaranteeing to final customers the respect of their expectations, including social responsibility issues.
\end{abstract}

Keywords: Network Social Responsibility; Global Values Chains; Network Governance; Network Management; Corporate Social Responsibility; Ethics; Global Markets

\section{Global Values Chains}

The aim of creating value characterises different businesses across the world and one of the most commonly adopted means of boosting value creation in international competitive environments is represented by the value chain management at a global level. The latter involves that the company is nowadays confronted by the threats and opportunities of multiple potential locations of the value chain activities across the globe. Identifying the best locations for the different activities, the best partners to conduct these operations - when they are not carried out internally through FDIs - and managing value systems, which are dispersed in different countries, have all become core strategic decisions and activities, on which the competitive positioning of the firm is built.

When Porter (1985) wrote his contribution on the value chain, the phenomenon was still at the beginning and in its work we can perceive the underlying assumption that the value chain was meant to be mostly internally organised by the firm and that location decisions, as well as partnering decisions, were not an issue, or at least not a key one. In the following twenty years, globalisation showed

\footnotetext{
*Full Professor of Marketing, University of Pavia (antonella.zucchella@ unipv.it)
} 
progressively its nature of transformative force (Nordhaug, 2002); the opportunities of doing business expanded both sectorally and geographically, together with the threats of global competition. Decisions regarding where to locate activities of the value chain and who could carry them out became fundamental in order to maintain and enhance competitiveness and value creation.

More recently growing attention has been devoted to the social responsiveness of firms and to the issue of their "good citizenship" in a global scenery. In approaching strategic decisions, the need of customer orientation has been complemented by the parallel need of social orientation (Maloni, Brown, 2006). The latter arises from different motivations: the most important one probably is represented by a growing demand from customers of socially responsible firms and products (demand-pull motivations), even though also some companies have pursued this behaviour as a ethical conduct of business (organisation- push motivations). Also environmental forces had a relevant impact (Gereffi, Sturgeon, Humphrey, 2005), such as the pressure of political movements, NGOs, public opinion, regulations, etc.

The value proposition of the firm to its market is not merely the result of "value extraction" across the world, by exploiting local resources and capabilities, but for a growing number of firms is a blend of value and values proposition, based on socially responsive behaviour.

This contribution aims at exploring this construct and at analysing its potentialities for firms' competitiveness. In particular this work proposes to complement the construct of value chain with the one of values chain, which is meant to provide evidence of the respect of values declared by the firm (respect of human rights, proper working conditions, equal opportunities, respect of the environment, contribution to local communities welfare,...) along the entire value chain in its different locations and for the activities carried out by different partners (outsourcers, strategic allies, subsidiaries, agents, and so on). A value chain shifts the emphasis from the practice of corporate social responsibility to the one of network social responsibility (NSR). It is widely recognised that economic action takes place more and more through business network, but the issue of social responsibility is still mainly treated at the corporate level and rarely at the network one (McGuire, Sundgren, Schneeweis, 1988; Wheeler, Colbert, Freeman, 2003).

This approach should not be viewed by firms as an additional cost/limit to action, imposed by external and internal constraints (consumers, opinion movements, trade unions, political parties, etc) but as an opportunity to deliver appealing value propositions to the market, where "value for money" issues are integrated with "value for values" ones and as an opportunity for the entire organisation to share company's values.

\section{The Emerging Characteristics of Value Chains}

The world of production has changed deeply over the last three decades. Production of final goods is more and more the result of value chains which are:

1. Dispersed across the globe;

2. Dispersed across different organisations. 
The dispersion of value chain activities can be seen as a building block of firm competitiveness, because it is the result of the companies' choices of the "best" locations for given activities (low labour cost, high productivity, unique competencies and resources, excellent knowledge, and so on) and the "best" partners for value creation (the most efficient/cheapest outsourcers, the business partners owning unique competencies and resources, the "right" cognitive distance, and so on). From this point of view, dispersion and heterogeneity both in terms of geographic locations and in terms of partners involved contributes to value creation and enhances international competitive positioning (Nohria, Ghoshal, 1997).

Some authors refer to these chains also as commodity chains: "A global commodity chain consists of sets of inter-organisational networks clustered around one commodity or product, linking households, enterprises and states to one another within the world economy" (Gereffi et al.,1994).

The network form is a common structural feature of global value chains: a significant amount of trade in the global economy (although it is difficult to quantify how much) is carried out in the form of transactions between subsidiaries of transnational companies. It is less widely recognised that trade is also organised through networks of legally independent firms using a variety of transactional relationships. Thirty years ago, Richardson (1972) referred to this as 'the dense network of cooperation and affiliation by which firms are inter-related'. Recent research suggests that such relationships can increasingly be found in international trade. Global value chain research in particular seeks to understand the nature of these relationships and their implications for development." (Nohria, Ghoshal, 1997; Humphrey, Schmitz, 2001).

The dispersion of value chains and the existence of network structures call for coordination of these dispersed value chain pieces and thus involves coordination costs as well as risks (Williamson, 1985). The former are mainly organisational costs related to the management of differentiated organisations located in different places. The latter are represented by a number of risks: this contribution focuses mainly on the risks associated with foreign partners/subsidiaries which are not aligned to the firm social responsiveness (if any). A third world partner employing children at work or a foreign subsidiary which deprives local resources, for example water or wood, or pollutes the environment are common cases of foreign partner behaviour which can affect seriously the reputation of the firm.

From this point of view, coordination of the value chain is not just a matter of improving business performance, but it turns into a strategic matter of guaranteeing to final customers the respect of their expectations, including social responsibility issues. For most consumers concern about the production chain behind each product has grown.

Actually the emerging issue of traceability is moving from its original field of application (food) to any product/service (Maloni, Brown, 2006). In its broad meaning traceability involves that the seller of the final good should guarantee the buyer/user not only about the physical fulfilment dimension of the product/service, but also about the quality and ethics of the processes behind it, even those dependent on different organisations in distant locations.

This implies a view of consumers' expectations along two different dimensions: product quality (including aesthetic and emotional aspects) and safety 
(individualism) and the impact of its value chain on the external environment pollution, labour conditions, local development and welfare.... - (collectivism).

The relevance of these issues in influencing consumers' behaviour varies across segments, but it tends to grow significantly over the last decades. For some consumers' groups (militant consumers), consumption choices are the new voting right in the global political scenery. Marketing research has to find out the quantitative relevance of this segment and - most important - its influence on the other segments' behaviour. A larger and even more influential segment is represented by socially responsible consumers: also in this case, their relevance is not only confined to the segment size but also to their attitude to influence progressively the behaviour of less socially sensitive segments (Antil, 1984).

External pressure to pursue socially responsive business practices do not only come from trends in consumers' behaviour, but also from the financial investors' side. According to a number of researches, there seems to be a positive or at least neutral relationship between CSR and financial performance (McGuire, Sundgren, Schneeweis, 1988; Hamilton, Jo, Statman, 1993). Moreover the so called militant investors are becoming a significant group, managing a significant portfolio of securities. Together with investors which only finance socially responsible firms, there is a larger and growing number of investors which do not finance activities which fall within certain categories or firms which have encountered problem of scarce social responsiveness.

Pursuing a project of quality traceability of the product extended to the social responsiveness issues and along dispersed networks of partners is a challenge for companies, but it also represents an opportunity to deliver both value to the customer and values to the system, unbundling innovative value propositions.

\section{Network Governance and Network Management as a Driver for Social Responsibility}

Networks are a fundamental organisational form for combining unique resources and competencies (Powell, 1990; Eisenhardt, Schoonhoven, 1996) and not just an alternative to market or hierarchy. Networks represent the prevailing form for organising global production, both for small and large companies, as commented above. Like any other structure, networks enable and limit action (Giddens, 1984; Nooteboom, 2004). In the above commented scenery, external pressures for socially responsive behaviour from customers, public opinion and investors are growing. The response of companies should primarily address the issue of network governance (Nooteboom, Gilsing, 2004).

First of all, "the concept of 'governance' is central to the global value chain approach. We use the term to express that some firms in the chain set and/or enforce the parameters under which others in the chain operate." (Humphery, Schmitz, 2001). In general, at the network level - among independent agents - the governance refers to "the inter-firm relationships and institutional mechanisms through which non-market coordination of activities in the chain takes place. This coordination is achieved through the setting and enforcement of product and process parameters to be met by actors in the chain" (Humprey, Schmitz, 2001). 
These assumptions highlight significant differences compare to the case of governance within a single firm.

Contrary to some beliefs, firms within networks are not really boundaryless (Ashkenas et al., 1995); this means that each company retains its distinctive core elements in terms of corporate values and culture (mostly embedded in local cultures and value systems). A dispersed network imposes relevant challenges as far as shared values need to be enforced. Network governance faces this challenge and plays a critical role regarding the adoption of some shared social values among partners, especially since the hierarchy mechanisms are quite weak in the case of global collaboration among independent agents.

According to Fichter and Sydow (2002) the conditions enabling networks to support corporate responsiveness are:

1. size of the network;

2. nature of ties (strength of strong ties - Krackhardt, 1992);

3. presence of hubs (hierarchical/coordination element).

In this contribution we added the issue of geographic dispersion as an additional factor of complexity. A crucial question when we move from CSR (corporate social responsibility) to NSR (network social responsibility) is the following one: are shared values a condition or an output?

If they are a pre-requisite it means that network governance and management rests upon partners selection according to given criteria (Geringer, 1991; Denicolai, 2008). A company which builds its international value chain selects on the basis of economic convenience, technical performance, partner's organisation competencies AND pre-defined standards of social responsiveness.

If NSR is an output derived from appropriate governance mechanisms and management practices, it means that network partners are progressively aligned to some shared values and corresponding "good practices" of social responsibility. This involves a stronger role of the hub organisation, which involves knowledge sharing, training, etc. In that sense, some best practices are the followings:

- partner selection (Geringer, 1991);

- resources commitment: foreign presence, integration of management practices, CSR office, reporting systems(Waddock et al., 2002);

- codes of conduct: support the network coordination in defining shared values and standards, enable auditing (Nooteboom, 2004).

The first option - partner selection - limits business choices and does not support directly the hub firm action in improving working and environmental conditions in foreign countries. The last two should co-exist because they reinforce each other: resources commitment engages the leading firm, codes of conduct involve also partners commitment (through relation- specific investments) and improve long term reciprocal commitment (Currall, Inkpen, 2002).

Codes of conduct (CC) involve development of trust, training and auditing activities and not just publishing some guidelines, so they call for resources commitment. The code of conduct is considered an answer at the firm level, sometimes encompassing some partners. While many large companies (and sometimes also small and medium sized ones) have adopted a $\mathrm{CC}$, the practice of 
network codes of conduct is much less widespread, even though it could be appropriate tool when moving from CSR to NSR.

The OECD has reported 246 codes (OECD, 2000, Scherrer, Greven, 2001) and this practice is apparently growing. The CC raises both enthusiasm and criticism: to someone it is ".... a patchwork of unilateral policy statements by single enterprises..."(Fichter, Sydow, 2002).

In order to make this practice more widespread and enforceable thorough appropriate institutional settings, some call for alternative/complementary answers at the institutional level? Examples such as SA800, ILO rules and agreements are mentioned as instruments which provide standards which could be adopted by companies and their networks, without the need of complex bargaining among partners regarding commonly accepted rules and standards.

The issue raised by Kant (1795) is more actual than ever. Institutions such as the ILO and similar bodies have been defined "toothless tigers". Without effective global political and regulatory institutions, firms (both large and small) are the leading rule setters, not only in the economic field. According to some authors (Sabel et al. 2000) the energy of competition could work in the interest of social responsibility. This is a typical feature of a global network, where competition and cooperation coexist. This issue is particularly important when firms compete pursuing a customer orientation strategy and customers are sensible to the social responsiveness issues behind the goods they buy. We commented on the argument of growing social sensitivity in consumer markets, and particularly of market segments (the militants and the socially sensitive) which could act as forerunners for larger segments. But for different markets segments across the world and new consumer groups in emerging economies price sensitivity can still overcome any social responsivity issue. This implies that a mix of stronger institutional actions and customer orientation pressures is needed to guarantee a desirable spread of NSR across the world.

Firms have organised production in global networks to a growing extent, where coordination issues arise, which mostly affect economic issues and value creation, but rarely shared values. Corporate responsibility practices are frequently more a flag than a practice for firms and tend to be bounded inside the firm. Social responsibility as a practice involves the existence of mechanism for governing and managing the network from the point of view of socially responsible behaviours.

Network management practices are still in their infancy, notwithstanding the spread of the network form as a mean to enhance value creation. The presence of network managers and inter-organisational routines are still difficult to find out even in large multinationals (Denicolai, 2008). The same holds for network monitoring and reporting practices as well for partner selection procedures.

\section{Conclusion}

When we consider CSR, we have the feeling that corporate responsibility practices are frequently more a flag than a practice and tend to be bounded inside 
the firm. This contribute proposes a model about product/service traceability based on the following issues:

- network shared values, incorporated in a network code of conduct;

- the implementation of shared values and code of conduct principles should rest upon the development of network governance and management practices. The latter should develop in the interest not only of NSR, but more generally in order to ensure an effective and efficient working of the network also for value creation and competitiveness. These practices vary from partner selection procedures to partnership monitoring, conflict management procedures and objectives alignments checks and finally to network reporting and performance (both economic and social) assessment. An appropriate organisational setting supports the development of these practices, routines and procedures. For example the creation of a network manager and her/his organisational unit could be helpful.

The role of hub firms is very important especially in the start up phase of the network, because a quasi-hierarchical coordination model of governance makes it easier to enforce common values and norms.

\section{Bibliography}

Antil J.H, Socially Responsible Consumers: Profile and Implications for Public Policy, Journal of Macromarketing, vol. 4, n. 2, 1984, pp. 18-39. http://dx.doi.org/10.1177/027614678400400203

Ashkenas R., Ulrich D., Jick T., Kerr S., The Boundaryless Organization: Breaking the Chains of Organizational Structure, Jossey-Bass, San Francisco, 1995.

Currall S.C., Inkpen A.C., A Multilevel Approach to Trust in Joint Ventures, Journal of International Business Studies, vol. 33, n. 3, 2002, pp. 479-495. http://dx.doi.org/10.1057/palgrave.jibs.8491027

Denicolai S., Competenze dinamiche di rete: strategie, modelli organizzativi e tecnologie per l'innovazione continua, Franco Angeli, Milan, 2008.

Eisenhardt K.M., Schoonhoven C.B., Effects of Founding Conditions on the Creation of Manufacturing Alliances in Semiconductor Ventures, H. Thomas, D. O'Neal (eds.), Strategic Integration, John Wiley and Sons, 1996.

Fichter M., Sydow J., Using Networks Towards Global Labor Standards? - Organizing Social Responsibility in Global Production Chains, Industrielle Beziehungen, vol. 9, n. 4, 2002, pp. 357380.

Gereffi G., Korzeniewicz M., Commodity Chains and Global Capitalism, Praeger, Westport, 1994.

Gereffi G., T. Sturgeon, J. Humphrey, The Governance of Global Value Chains, Review of International Political Economy, vol. 12, n. 1, 2005, pp. 78-104. http://dx.doi.org/10.1080/09692290500049805

Geringer J.M., Strategic Determinants of Partner Selection Criteria, International Joint Ventures, Journal of International Business Studies, vol. 22, n. 1, 1991, pp. 41-62. http://dx.doi.org/10.1057/palgrave.jibs.8490291

Giddens A., The Constitution of Society; Outline of the Theory of Structure, University of California Press, Berkeley, 1984. 
Hamilton S., Jo H, Statman M., Doing Well while Doing Good? The Investment Performance Of Socially Responsible Mutual Funds, Financial Analysts Journal, vol. 49, n. 6, Nov-Dec 1993, pp. 6266.

http://dx.doi.org/10.2469/faj.v49.n6.62

J. Humphrey, H. Schmitz, Governance in Global Value Chains, Institute of Development Studies, 32.3, 2001.

http://dx.doi.org/10.1111/j.1759-5436.2001.mp32003003.x

Kant E., Perpetual Peace: A Philosophical Sketch, 1795.

Krackhardt, D., The Strength of Strong Ties: the Importance of Philos in Organization, N. Nohria, R.C. Eccles (Eds.), Networks and Organizations: Structure, Form, and Action, , Harvard Business School Press, Boston, 1992, pp. 216-239.

Maloni M., Brown M., Corporate Social Responsibility in the Supply Chain: an Application in the Food Industry, Journal of Business Ethics, vol. 68, n. 1, 2006, pp. 35-52. http://dx.doi.org/10.1007/s10551-006-9038-0

McGuire J. B., Sundgren, A., Schneeweis T., Corporate Social Responsibility and Firm Financial Performance, Academy of Management Journal, vol. 31, n. 4, 1988, pp. 854-872. http://dx.doi.org/10.2307/256342

Nohria N., Ghoshal S., The Differentiated Network: Organising Multinational Corporations for Value Creation, Jossey Bass, San Francisco, 1997.

Nooteboom B., Interfirm Collaboration, Learning and Networks, Routledge, London, 2004.

Nooteboom B., Gilsing V. A., Density and Strength of Ties in Innovation Networks: A Competence and Governance View, Report Series, Erasmus Research Institute of Management, 2004.

Nordhaug K., Globalization and the State: Theoretical Paradigms, European Journal of Development Research, vol. 14, n. 1, 2002, pp. 5-27. http://dx.doi.org/10.1080/714000408

OECD, Science, Technology and Industry Outlook, 2002.

Porter M. E., Competitive Advantage, The Free Press, New York, 1985.

Powell W. W., Neither Market nor Hierarchy: Network Forms of Organization, B. Staw, L. L. Cumming (eds.), Research in Organizational Behaviour, JAI Press, Greenwich, 1990.

Richardson G. B., The Organisation of Industry, Economic Journal, n. 82, 1972, pp. 883-896. http://dx.doi.org/10.2307/2230256

Sabel C., O'Rourke D., Fung A., Ratcheting Labor Standards: Regulation for Continuous Improvement In The Global Workplace. Version 2.0, February 23, 2000. (http://www.law.columbia.edu/sabel/papers/ratchPO.html).

Scherrer C, Greven T., Global Rules for Trade: Codes of Conduct, Social Labelling, Workers Rights Clauses, Münster, 2001.

Waddock Sandra, Leading Corporate Citizens: Vision, Values, Value Added. McGraw-Hill, New York, 2002.

Wheeler D., Colbert B., Freeman R. E., Focusing on Value: Reconciling Corporate Social Responsibility, Sustainability and a Stakeholder Approach in a Network World, Journal of General Management, vol. 28, n. 3, 2003, pp. 1-28.

Williamson O.E., The Economic Institutions of Capitalism: Firms, Markets, Relational Contracting, Free Press, New York, 1985. 